Also by Paul R. Ferguson and Glenys J. Ferguson

BUSINESS ECONOMICS: The Application of Economic Theory (with R. Rothschild) 


\section{Industrial Economics}

\section{Issues and Perspectives}

SECOND EDITION

Paul R. Ferguson and Glenys J. Ferguson 
All rights reserved. No reproduction, copy or transmission of this publication may be made without written permission.

No paragraph of this publication may be reproduced, copied or transmitted save with written permission or in accordance with the provisions of the Copyright, Designs and Patents Act 1988, or under the terms of any licence permitting limited copying issued by the Copyright Licensing Agency, 90 Tottenham Court Road, London W1T 4LP.

Any person who does any unauthorised act in relation to this publication may be liable to criminal prosecution and civil claims for damages.

The authors have asserted their rights to be identified as the authors of this work in accordance with the Copyright, Designs and Patents Act 1988.

Published by

PALGRAVE MACMILLAN

Houndmills, Basingstoke, Hampshire RG21 6XS and 175 Fifth Avenue, New York, N. Y. 10010 Companies and representatives throughout the world

PALGRAVE MACMILLAN is the global academic imprint of the Palgrave Macmillan division of St. Martin's Press, LLC and of Palgrave Macmillan Ltd. Macmillan $\otimes$ is a registered trademark in the United States, United Kingdom and other countries. Palgrave is a registered trademark in the European Union and other countries.

This book is printed on paper suitable for recycling and made from fully managed and sustained forest sources.

A catalogue record for this book is available from the British Library. 


\section{Contents}

List of Figures

List of Tables

$\mathbf{x i}$

Acknowledgements

xiii

Preface to the First Edition

XV

Preface to the Second Edition

xvii

1 Introduction

1.1 Introduction

1.2 What is industrial economics?

1.3 Theoretical foundations of industrial economics

1.4 Developments within the neoclassical paradigm

1.5 Developments outside the neoclassical paradigm

1.6 Evaluation criteria

1.7 Issues discussed in this book 10

\begin{tabular}{ll}
1.8 & Guide to further reading \\
\hline
\end{tabular}

2 The Structure-Conduct-Performance Paradigm 13

$\begin{array}{lll}2.1 & \text { Introduction } & 13\end{array}$

$\begin{array}{ll}2.2 \text { What is structure? } & 14\end{array}$

2.3 Conduct and performance 15

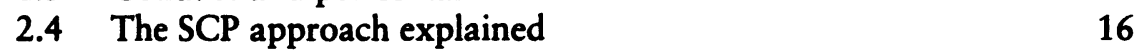

2.5 Relationships between structure, conduct and performance 17

2.6 Neoclassical developments of the SCP approach 18

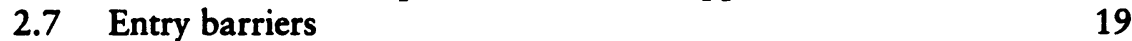

2.8 Tests of SCP $\quad 22$

2.9 Problems of measuring variables $\quad 23$

2.10 Markets and industries $\quad 24$

2.11 Use of data at the level of the firm 26

2.12 Changes in market structure $\quad 27$

2.13 The neoclassical basis 27

2.14 The contributions of Clark and Andrews 29

2.15 The Austrian critique 31

2.16 An example of the Austrian approach 32

2.17 The transaction cost critique 34

2.18 Implications for empirical work 35

$\begin{array}{ll}2.19 \text { Conclusion } & 37\end{array}$ 
3 Market Concentration $\quad 38$

3.1 Introduction $\quad 38$

3.2 Market concentration and structure 38

3.3 Alternative measures of market concentration 39

3.4 Theoretical considerations 43

3.5 Hannah and Kay axioms 44

3.6 Further comparisons of market concentration measures 46

3.7 Concentration measures in practice 48

3.8 The effects of international trade on concentration 51

3.9 Trends in concentration 53

3.10 Criticism of the use of concentration 55

3.11 Conclusion $\quad 58$

4 The Advertising Debate $\quad 60$

$\begin{array}{lll}4.1 & \text { Introduction } & 60\end{array}$

4.2 What is advertising? $\quad 61$

4.3 Why advertise? 62

4.4 How much advertising? 63

$\begin{array}{ll}\text { 4.5 Advertising and market structure } & 67\end{array}$

4.6 The costs of advertising $\quad 69$

4.7 The 'advertising as persuasion' view 70

4.8 The 'advertising as information' view $\quad 72$

4.9 Incorporating a retail sector $\quad 74$

4.10 Advertising and market concentration 75

4.11 Advertising and market share instability 76

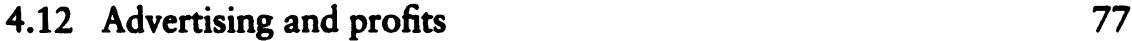

4.14 Advertising and entry barriers $\quad 78$

4.15 Advertising and prices $\quad 79$

$\begin{array}{ll}4.16 \text { Conclusion } & 81\end{array}$

5 Monopolies - Good or Bad? 83

$\begin{array}{lll}5.1 & \text { Introduction } & 83\end{array}$

5.2 Monopolies and market power $\quad 84$

5.3 The impact of market power on economic welfare 84

5.4 Monopolies with costs lower than the competitive reference 86

5.5 Reasons for the development of monopoly 87

5.6 Harberger's welfare loss estimates $\quad 88$

5.7 Criticisms of the Harberger approach 89

5.8 Cowling and Mueller and the calculation of welfare loss 90

5.9 Masson and Shaanan and the calculation of welfare loss 92

5.10 Summary of welfare loss estimates 93

5.11 The relationship between market structure and profit 95

5.12 Other tests of the market power/efficiency hypotheses 97

5.13 The persistence of abnormal profits 98

$\begin{array}{ll}5.14 \text { The effect of entry } & 101\end{array}$ 


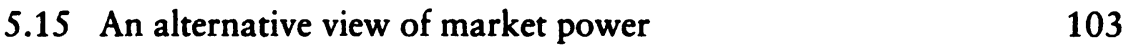

$\begin{array}{ll}5.16 \text { Conclusion } & 107\end{array}$

6 Invention, Innovation and Diffusion 108

$\begin{array}{lll}6.1 & \text { Introduction } & 108\end{array}$

6.2 Change in the pharmaceutical market 109

6.3 The process of change 111

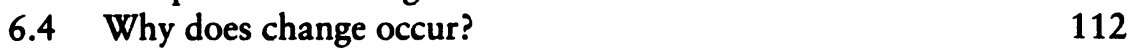

6.5 Invention and innovation 116

$\begin{array}{ll}\text { 6.6 The importance of innovation } & 118\end{array}$

6.7 The welfare effects of product innovation 119

$\begin{array}{ll}\text { 6.8 The welfare effects of process and organisational innovation } 121 & 12.0\end{array}$

6.9 An alternative view of the welfare effects of process innovation 122

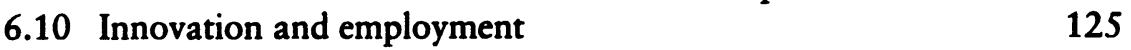

6.11 The diffusion of innovation 127

6.12 Characteristics of firms and markets prominent in the process of change $\quad 130$

6.13 Conclusion 135

7 The Foundations of Industry Policy 136

$\begin{array}{lll}7.1 & \text { Introduction } & 136\end{array}$

$\begin{array}{ll}7.2 & \text { What is industry policy? } \\ 7.37\end{array}$

$\begin{array}{lll}7.3 & \text { The theoretical case for industry policy } & 138\end{array}$

7.4 Market failure arising from monopoly 139

$\begin{array}{lll}7.5 & \text { Public goods } & 140\end{array}$

$\begin{array}{lll}7.6 & \text { Externalities } & 142\end{array}$

$\begin{array}{lll}7.7 & \text { Common property rights } & 144\end{array}$

7.8 Differences between private and social time preference rates 144

7.9 Government intervention to correct market failure 145

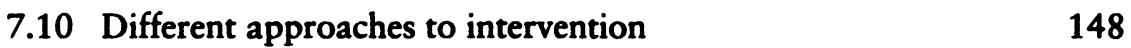

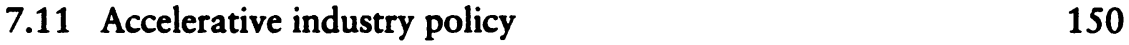

$\begin{array}{lll}7.12 & \text { Decelerative industry policy } & 153\end{array}$

$\begin{array}{ll}7.13 \text { Neutral industry policy } & 156\end{array}$

$\begin{array}{ll}7.14 \text { Conclusion } & 158\end{array}$

8 Industry Policy in Practice 160

$\begin{array}{lll}8.1 \text { Introduction } & 160\end{array}$

$\begin{array}{ll}8.2 \text { Policy implementation } & 160\end{array}$

$\begin{array}{ll}\text { 8.3 Competition policy } & 162\end{array}$

$\begin{array}{ll}\text { 8.4 Competition policy in practice } & 163\end{array}$

$\begin{array}{ll}\text { 8.5 Policy towards monopoly } & 165\end{array}$

8.6 Policy towards mergers 166

8.7 Policy towards restrictive and anti-competitive practices 169

8.8 Policy towards state entry barriers 171

$\begin{array}{ll}\text { 8.9 Evaluation of competition policy } & 172\end{array}$

$\begin{array}{ll}8.10 \text { Regional policy } & 174\end{array}$ 
$\begin{array}{ll}\text { 8.11 Regional policy in practice } & 178\end{array}$

$\begin{array}{ll}8.12 & \text { Innovation policy } \\ 8.13 & 180\end{array}$

8.13 Innovation policy in practice 183

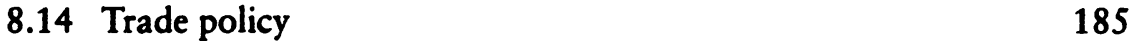

8.15 Trade policy in practice 187

8.16 An integrated industry policy - the case of the EC 189

8.17 Conclusion 192

9 State or Private Control? 194

$\begin{array}{lll}9.1 & \text { Introduction } & 194\end{array}$

9.2 Theoretical arguments for state control 195

9.3 State control of natural monopoly 197

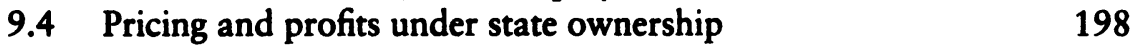

9.5 Pricing and profits under regulation 200

9.6 Investment under state control 201

9.7 Problems of enforcing state control 202

9.8 What is privatisation? 204

9.9 The natural monopoly argument revisited 205

$\begin{array}{ll}9.10 \text { Ownership arguments } & 207\end{array}$

9.11 Empirical evidence on ownership arguments 211

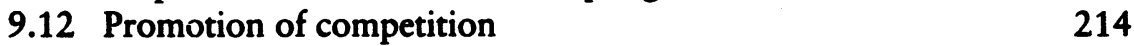

9.13 Franchising as a means of promoting competition 216

9.14 Empirical evidence on the promotion of competition 218

9.15 Where are the greatest gains from privatisation? 220

9.16 Privatisation in the UK 221

9.17 Privatisation in the USA 226

9.18 Privatisation in Chile $\quad 227$

$\begin{array}{ll}9.19 \text { Conclusion } & 228\end{array}$

10 Deindustrialisation $\quad 230$

10.1 Introduction $\quad 230$

10.2 What is deindustrialisation? 231

10.3 Is deindustrialisation a problem? 235

10.4 Theoretical framework for the analysis of deindustrialisation 236

10.5 The stages of growth argument 237

10.6 Loss of competitiveness 239

10.7 Multinationals and deindustrialisation $\quad 240$

10.8 The state sector's contribution 242

10.9 The Dutch disease 243

10.10 Services as a substitute for industry 244

10.11 Links between industry and services $\quad 247$

10.12 A disaggregated view of changes in industry 250

10.13 Multinationals and the revitalisation of industry 253

10.14 Policy on deindustrialisation $\quad 255$

$\begin{array}{ll}10.15 \text { Conclusion } & 257\end{array}$ 
Appendix 1 An Example of the Approach of the New Industrial Organisation

Appendix 2 The Dorfman and Steiner Condition for Optimal Advertising Levels

Appendix 3 Harberger's Method of Estimating the Welfare Effects of Monopoly

Appendix 4 Cowling and Mueller's Method of Estimating the Welfare Effects of Monopoly

References

Author Index

Subject Index 


\section{List of Figures}

2.1 The traditional SCP approach

2.2 More complex relationship between structure, conduct and performance

3.1 Comparison of concentration curves 40

3.2 Derivation of the Gini coefficient from the Lorenz curve 42

4.1 The optimal level of search

4.2 Advertising intensity and market concentration 68

4.3 Responsiveness of sales to level of advertising $\quad 70$

4.4 The 'advertising as persuasion' view 71

4.5 The 'advertising as information' view 73

5.1 Reduction in economic welfare due to monopolisation 85

5.2 The effects on welfare of a monopoly with costs lower than in perfect competition

6.1 Ranking of firms in the US market for ethical pharmaceuticals (firms ranked by market share)

6.2 Innovation from an Austrian/evolutionary perspective 115

6.3 Incremental product innovation under monopoly 120

6.4 Process innovation in a perfectly competitive market 122

6.5 Process innovation in a monopoly 123

6.6 Dynamic analysis of the welfare effects of innovation 124

6.7 The impact of a process innovation on factor employment in a perfectly competitive industry

6.8 The time path of diffusion of a process innovation 129

7.1 The public good argument for market failure 141

7.2 The externality argument for market failure 143

8.1 The effect of a voluntary export restraint 186

9.1 Natural monopoly 199

9.2 Gains and losses from privatisation 210

10.1 The stages of economic growth 238

A1.1 Cournot duopoly 263 


\section{List of Tables}

1.1 Economic approaches employed in this book 4

2.1 Comparison of the structures of two hypothetical markets 17

2.2 The characteristics of workable competition 30

3.1 Comparison of summary measures of concentration 46

3.2 Comparison between the SIC 92 and SIC 80 classification of soft furnishings

3.3 Comparison of aggregate concentration levels in manufacturing, 100 -firm concentration ratios

3.4 Trends in seller concentration in selected UK manufacturing industries, 1980-9, five-firm concentration ratios

calculated by net output

3.5 Average five-firm concentration ratios for the UK, with and without adjustment for international trade

3.6 Levels of concentration in the automobile market before and after adjustment for international trade

4.1 Media distribution of advertising expenditures, 1990 (percentage) 61

4.2 Advertising as a percentage of GDP in selected countries

4.3 Advertising intensities by product groups for the UK, 1991

4.4 Summary of the empirical evidence on the relationship between advertising and prices

$\begin{array}{lll}4.5 & \text { Prices of the cheapest prescribed standard spectacles by country } & 81\end{array}$

5.1 Welfare changes due to monopolisation 86

5.2 Cowling and Mueller's estimates of welfare loss due to monopoly 92

5.3 Summary of empirical studies on the welfare effects of monopoly 94

6.1 Business research and development expenditures by industry as a percentage of value-added for selected industries, 1988

7.1 Taxonomy of industry policies

8.1 Competition powers of the European Community as given in the Treaty of Rome

8.2 Likelihood of challenge under the Department of Justice

\section{Horizontal Merger Guidelines for the USA}

9.1 Monopoly - state control and the privatisation options 222

10.1 Percentage of total employment in the industrial sector 232

10.2 Employment in the industrial sector (millions) 232

10.3 Index numbers of industrial production (base $1985=100$ ) 233

10.4 Trade balances (billion SDRs) 234

10.5 Share of world exports of manufactures (percentage) 234

10.6 Employment in services (millions) 
10.7 Percentage of total employment in services

10.8 Employment in services in the USA, selected industries (percentage change over period)

10.9 Employment in manufacturing in the USA, selected industries (percentage change over period)

10.10 Industries ranked by growth in output, showing principal explanation 


\section{Acknowledgements}

The authors and publishers wish to thank the following who have kindly given permission for the use of copyright material:

The Advertising Association for material from Waterson (1992) and Advertising Statistics Yearbook (1992, 1993).

The Economist for material from 15 March 1986 issue of The Economist.

Every effort has been made to trace all copyright-holders, but if any have been inadvertently overlooked the publishers will be pleased to make the necessary arrangement at the first opportunity. 


\section{Preface to the First Edition}

The industrial economics courses taught at the University of Lancaster have always been rather heretical. Philip Andrews and Elizabeth Brunner had an enduring belief in the strength of competition and were sceptical of the relevance of the 'structure-conduct-performance' (SCP) approach which dominated the subject. Harry Townsend, following the eclectic tradition of the London School of Economics, had a similar distaste for this paradigm, believing it to be too constraining. As long ago as 1972, he introduced transaction costs as a key element of the undergraduate industrial economics course, but even today this topic is ignored (or given scant attention) in many such courses elsewhere. Hence, as both a student and a lecturer at Lancaster, I have been made aware of alternative interpretations and approaches to the study of industrial economics which are only now beginning to receive wider recognition.

The Lancaster tradition of non-conformity is continued in this book which differs in scope from other texts in the field of industrial economics. It covers the mainstream analysis, but challenges this approach - and the resulting policy conclusions - by introducing many of the less well-known developments in the area.

Without the help of many friends and colleagues, this book would have taken much longer to write. Andrea Pezzoli made many valuable comments while Harry Townsend gave enthusiastic support and help. Ron Bowen's lack of knowledge of economics, but careful attention to detail, removed much of the jargon. The boundless energy and enthusiasm of Professor Balasubramanyam led me to discover that I could work twice as hard as I had previously thought possible. My greatest debts are to Gerry Steele, who amazed me by his capacity to examine meticulously every draft I produced (and, furthermore, by his claim to enjoy such an onerous task) and to my wife, Glenys. As the book slowly advanced, she decided that the fastest way to rediscover leisure would be to help me. She finished up spending as long on the book as I did, and, in this sense, it is as much her effort as mine. Nevertheless, any remaining errors are my own responsibility.

This is the point where authors traditionally thank their secretary for her miraculous ability to decipher almost illegible handwriting; in this case thanks must go to my word-processor. Furthermore I believe that I could have dispensed with the technical skills of the publisher and typesst the book myself. In fact, I could have performed all the 
publisher's tasks equally well, given the assumption that information is perfect, and in the absence of uncertainty and transaction costs. But if that were the case there would also have been no need for me to write this book, and I would be doing a different job.

PAUL R. FERGUSON 


\section{Preface to the Second Edition}

Since writing the first edition, we have become more aware of the great differences between individual firms, both within and across markets and industries. An advantage of writing a second edition is that it requires the authors to find the time to become immersed in the recent literature. Among other things, it became evident that we are by no means alone in realising that individual firms deserve more consideration in analysis.

Whilst the first edition presented the work of the Austrian School as the main counter to the traditional (neoclassical) paradigm, the second edition widens the theoretical approaches considered. It now encompasses all the major variants of what is becoming known as the new institutional economics, with, in particular, more attention being given to transaction cost economics (associated principally with Williamson and North). Not only does the second edition adopt a wider theoretical compass, but the discussion of empirical work, the tables and examples have been thoroughly updated. All the chapters have been rewritten, but some have changed more than others. For instance, those on industry policy in practice and state against private control are now substantially different.

The re-writing of this book was hastened by the addition of a second author. Glenys Ferguson shouldered a substantial proportion of the work, and this is reflected in the joint authorship. As with the first edition, considerable credit must be given to Gerry Steele, who re-examined every word with diligence. John Finch provided valuable comments on the various theoretical paradigms introduced in Chapter 1.

PAUL R. and GLENYS J. FERGUSON 